\title{
Relationship Between Accounting Practices and Management of Funds In Public Secondary Schools in Kisii County, Kenya
}

\author{
Grace Ndinda Kimuyu*, Isaac K Naibei**, Hellen W. Sang*** \\ *School of Business and Economics, University of Kabianga, Kenya \\ **School of Business and Economics, University of Kabianga, Kenya \\ ***School of Business and Economics, University of Kabianga, Kenya
}

DOI: 10.29322/IJSRP.11.12.2021.p12045

http://dx.doi.org/10.29322/IJSRP.11.12.2021.p12045

\begin{abstract}
This study sought to determine the relationship between accounting practices and management of funds in public institutions in Kisii County. Specifically, the study sought to; determine the relationship between budgeting practices and management of funds, explore the relationship between book keeping practices and management of funds, explore the relationship between internal control practices and management of funds and examine the relationship between automation accounting and management of funds in public institutions in Kisii County. Target population was 352 schools where the school bursars and the Principals were the respondents. Stratified random sampling was used to select 187 respondents who were school bursars. The study used correlation research design and the primary source of data was self-administered questionnaire. Validity of the instrument was achieved by using experts in the field while reliability was determined using Cronbach Alpha coefficient test, which was 0.87. The data was analyzed using inferential and descriptive statistics with the aid of SPSS software and the results presented using the percentages, mean and mode to draw the conclusions. The finding indicated that budgeting significantly affected funds management $(\mathrm{P}<0.05)$. Bookkeeping was found to have positive significant to funds management $(\mathrm{P}<0.05)$, budgeting practices had a significance of $(\mathrm{P}<0.05)$, Internal control practices had a significance of $(\mathrm{P}<0.05)$ and accounting automation had a significance of $(\mathrm{P}<0.05)$. The research concludes that budgeting, bookkeeping and internal control significantly affect the funds management. The study recommends that government through Ministry of Education to standardize the automation and use of computerized accounting systems.
\end{abstract}

Key words: Accounting Practices, Management of Funds, Public Secondary Schools, Kenya

\section{INTRODUCTION}

Investment in public institutions is one of the most effective mechanisms of mitigating poverty, improving monetary and advancing human rights. Thus, the governments across the globe recognize the significance of gaining knowledge on funds management in public sector (Omondi et al. 2016). In this situation, numerous nations have devolved the control of financial sources to mastering establishments to beautify their overall performance (Crouch et al, 2008). Proper management of price range in instructional establishments may be very vital to their operations (Munge, Kimani \& Ngugi, 2016). However, around the arena the control of funds in most public institutions round the sector has been coupled with many challenges such as corruption, mismanagement and growing cost of maintenance (Crouch \&Winker, 2008). Rosalind \& Downs (2004) were of the view that it was almost impossible to find someone from the local community who understood the funding system and had an idea about the value received by the schools in Brazil, Poland and England.

The same authors indicated that in Brazil, Poland and England very few parents participated in school administration. Usually, there were one or two parents' representatives on the school board probably those were the only parents who were aware of the sum received by the schools and its uses. South African School Act (SASA) of 1996 created School Governing Bodies (SGBs) that include the principal, elected representatives of parents, teachers, non-teaching staff and students. Segment 21 of SASA commands the SGBs to be responsible for keeping up schools" property, buy of course books, instructive materials or gear and pay for administrations rendered to the school. Nombasa, (2004) revealed that most SGBs in SA lacked skills in drafting of budgets, writing financial and policy statements, control of finance and petty cash, initiative and innovation as well as accountability. The main reason was illiteracy and lack of training. Education is one of the important and meaningful social economic development and 
reduction of poverty levels in most third world countries.

According to Nyakundi et al (2013), most African nations resolved to offer free, compulsory and universal primary education, increase enrollment to secondary schools by $30 \%$ of the children who successfully completes the basic primary education, raise transition to higher education by $20 \%$ and to improve quality as far as education in all educational institutions. To achieve, objective of education provision to their citizens, most of the developing increased their budgetary allocations on education and in some countries; the expenditure on education exceeds overall gross national product. Such has the tenancy of exerting a lot of pressure on other segments of the economy thus it is vital to monitor and control expences on learning matters (Nyakundi et al., 2013).

In Kenya, the responsibility of control and management of funds allocated to public secondary schools from parents as well as guardians and sponsors, central and the county governments is bestowed to the Boards of Managements (BOMs). The Kenya Basic Education Act (2013) allows the Board of Management to establish audit committees to facilitate internal control and auditing in public secondary schools (Kenya Gazette Supplement, 2013). The audit committee generates and submits audit reports to the board of management, which in turn comes up with an annual audit report, which is then director of basic education. The Education Act also stipulates that the audit department of the Ministry of Education should audit all the annual accounts of educational institutions, which are funded through public funds. Additionally, approved accounting and auditing firms are also allowed to audit public education institutions but this requires written permissions and approval from the cabinet secretary in charge of education (Kenya Gazette Supplement, 2013).

The Kenyan education system is troubled by financial risk management and the greatest risky areas being resource allocation and utilization which have created a fertile ground for funds embezzlement and corruption. Thus, proper accounting is required in public schools to manage and utilize the huge amount of funds allocated to those institutions. With the ministry of education channeling millions of shillings through different schemes such as the free secondary school programme, bursary schemes and infrastructural funding programmes, dissatisfaction by parent and students remains a great concern due lack of accountability and incompetence in public schools (Nyakundi et al., 2013). For instance, creditors and debtors in public secondary schools have been on the increase with a good example in the rear 2008 the creditors and debtors in public secondary schools had accumulated to Ksh. 5.5 billion and 15.5 billion respectively (Republic of Kenya, 2008).

Accounting practice is defined as a process of collecting, transforming, reporting and disseminating reports to various users. Accounting practice entails presenting accounting information to the management of the organization and it's used for efficient administration of resources and supports appropriate decision-making (Nupakorn \& Phapruke, 2010). Accounting practices play the main part in determining the framework of accounting information and financial reporting that both internal and external users utilize to evaluate financial performance of the organization. Therefore, accounting practices are concerned with records maintenance of an educational institution in which the financial transactions are summarized (Sigilai \& Bett, 2013). Some of the accounting practices include budgeting, book keeping, internal control activities and computerized accounting. Budgeting is a foundation of most organization's control process mostly used by the management and it is a key tool in accounting that institutions utilize in implementation of organizational strategies (Ostergren \& Stensaker, 2011).

It is a very crucial for sound financial reporting especially for public schools. In public secondary schools, the board of management approves a school budget and it shows the income and expenditure plans based on an institutions development plans for a particular year. A school budget directs and controls the institutions income and expenditure plan while satisfying the schools objectives (Omoro, 2005). Proper budgeting is a useful connection between planning and evaluation. Through proper budgeting, educational institutions can achieve their intended goals effectively (Kiriza, Walela \& Kukubo, 2015). Bookkeeping entails entering accounting transactions in relevant books of accounts. One of the routine finance functions that can be delegated to junior staff in an organization is record keeping and safeguarding property and documents of an organization (Otieno \& Nyangechi, 2013). The intent of financial statements is to provide information on the state of affairs financially, financial position effectiveness and changes which are useful in economic decision-making (Horvat, 2007).

Financial records, for example items like cash receipt books, general ledgers, petty cash book, purchases day book, cheque payments book, general journal, nominal and so on must be maintained and kept in a fundamental systems of accounting (Maseko \& Manyani, 2011). Public secondary schools in Kenya normally maintain receipt books, Cashbooks, payment vouchers, journals; school levies registers, financial ledgers and bank monthly statements (Omoro, 2005). Internal controls are mechanisms through which an entity provides useful information, which is important for decision-making. Strong internal controls, which include frequent monitoring by school committees, will have a bearing on well-managed funds (Otieno \& Nyangechi, 2013). Internal control comprises of checking, autonomous assessment as well as efficient reporting to the organization to make sure that all the actions of the organization are performed according with current plans, directions as well as limits (Bayyoud \& Sayyad, 2015).

Internal controls make it possible for the head teachers to make an effective and speedy check on the rate of expenditure and proper financial management. Internal controls provide independent evaluation of the schools financial control and management This publication is licensed under Creative Commons Attribution CC BY. 
systems (Horvat, 2007). Computerized accounting-system is considered to be a computer-based structure, which joins accounting concepts and principles plus the model of information system to record, practice, examine and yield monetary info (Gelinas, Sutton \& Hunton, 2005). If an organization fails to use computers and computer software it means that accounting information may not be accurate and the organization may experience delays in financial reporting and lack of permanent accounting records and information. Computerization of departments increases coordination and cohesiveness therefore leading to attainment of the organization's goals. Use of computers especially in the bookkeeping, generation of receipts and payment vouchers and stores control is key to management efficiency in public schools (Otieno \& Nyangechi, 2013).

The Education Act also stipulates that the audit department of the Ministry of Education should audit all the annual accounts of educational institutions, which are funded through public funds. Additionally, approved accounting and auditing firms are also allowed to audit public education institutions but this requires written permissions and approval from the cabinet secretary in charge of education (Kenya Gazette Supplement, 2013). The Koech report (1999) also noted a backlog in the audit of Education Institutions as a major factor contributing to mismanagement of funds. "It is unfortunate that a number of school heads do not submit books of accounts in time, to the district school's auditors for audit. This has led to backlog of unaudited reports dating as far back as $1995 / 96$. This leads to a situation where the issues raised are in most cases overtaken by events such as transfers or retirements Prof. Mutahi, Permanent Secretary, MOEST (2003). Financial risk management and the greatest risky Centre being resource allocation and utilization that have created a fertile ground for funds embezzlement and corruption trouble the Kenyan education system. Consequently, proper accounting and auditing practices are required in public schools to monitor the use of the enormous amount of funds allocated to these institutions. With the ministry of education channeling millions of shillings through different schemes such as the free secondary school programme, bursary schemes and infrastructural funding programmes, dissatisfaction by parent and students remains a great concern due to lack of accountability and incompetence in public schools (Nyakundi et al., 2013). For instance, creditors and debtors in public secondary schools have been on the increase with a good example in the year 2008 the creditors and debtors in public secondary schools had accumulated to Ksh. 5.5 billion and 15.5 billion respectively (Republic of Kenya, 2008).

The present secondary learning platform is directed towards meeting the requirements of both the learners that terminate their learning after secondary school as well as the ones to proceed for higher learning. The governments and other associations finance the public secondary schools. There has been incredible upsurge in the number of secondary and in students' admission in reaction to the promptly up surging number of Secondary school graduate looking for an entry to the secondary level. There are sixty Public Secondary Schools in Kisii County. Sound financial management is important in schools though due to wide scope and diversity in non-profit organizations and their activities, proper financial management may turn out to be more complex than in profit making organizations (Omoro, 2005). Kisii County is situated in western Kenya, Lake Region. It consists of nine Sub-Counties namely; Gucha South, Sameta, Masaba South, Kisii Central, Gucha, Kisii South, Nyamache, Marani and Kenyenya. Kisii County has 60 public secondary schools. The schools are distributed among the nine sub counties as follows; Gucha South 10, Sameta 3, Masaba South 7, Kisii Central 9, Gucha 3, Kisii South 4, Nyamache 3, Marani 4.

Proper management of finances in educational institutions is very imperative to their operations. However, around the world the management of funds in most public educational institutions has been coupled by a lot of challenges among them are corruption, mismanagement, rising cost of education and unplanned expansion (Mobegi, Ondigi \& Simatwa, 2012). In Kenya, the government has heavily invested in education and budgetary allocations to the Education Ministry ranges between $13.5 \%$ and $16.5 \%$ of the national budget with budgetary allocations to public secondary schools accounting for $23 \%$ of the Ministry's budget. However, concerns over fees arrears accuracy remains a great concern and questions on funds management in public secondary schools remains unanswered and there are serious financial challenges in most public secondary schools.

Otieno and Nyangechi (2013) studied the efficiency of internal control processes and administration effectiveness of free primary learning finance and found that the use of internal control procedures are effective on management efficiency of funds in schools. Mobegi, Ondigi and Simatwa (2012) discovered the features leading to monetary misappropriation and mismanagement in secondary schools and found that the key factors which include corrupt promotion modes, lack monetary training and feeble board of management, weak internal control apparatuses, poor auditing procedures, unqualified account clerk, community and sponsors interventions. However, most studies concentrated more on financial management practices in educational institutions and not accounting practices. This has created a gap in literature, which this study intends to seal by examining the relationship between accounting practices and management of public funds among Public Secondary in Kisii County. The general objective of the study was to examine the relationship between budgeting processes and management of funds among public secondary schools in Kisii County.

\section{RESEARCH METHODOLOGY}

This publication is licensed under Creative Commons Attribution CC BY.

http://dx.doi.org/10.29322/IJSRP.11.12.2021.p12045 
A research design is a set of choices that makes up the master plan stipulating the methods and processes for gathering and examining the needed information (Mathoko, 2007). The type of research design used in conducting this research was correlation research design. Correlation survey research design is a scientific method, which encompasses observing and defining the conduct of a subject without any manipulation. It was deemed appropriate because it involved collecting data in order to address the questions on the existing position of the matters of the research (Kothari, 2004). The design also allowed the researcher to generate both numerical and descriptive data information that was utilized in estimating connections among factors and it empowered the researcher to generalize its findings. The study used quantitative methodologies in the gathering of information. The methodology empowers information to be methodically gathered and dissected to give a graphic record of the factors under investigation.The study was conducted in public secondary schools in Kisii County situated in part of Nyanza, Lake Region. It consists of nine SubCounties namely; Gucha South, Sameta, Masaba South, Kisii Central, Gucha, Kisii South, Nyamache, Marani and Kenyenya.

A population is the whole measurements gathering of people or things that make up the total of all probable measurements in the research scope. The target population for this study was made up of the 365 public secondary schools bursars in Kisii County. A representative's sample from the accessible population was selected. The sample was selected using stratified sample random sampling technique whereby the schools were categorized to four strata: National, Extra County, County and Sub-County schools. A proportional sample was selected from each category in order to determine the sample size. Yamane (1967) formula was used to compute the sample size which gave a sample of 190 and was distributed among the categories of schools as shown in Table 3.1.

$\mathrm{n}=$ $1+\mathrm{N}(\mathrm{e})^{2}$

Where $\mathrm{n}=$ sample size, $\mathrm{N}=$ Target Population size, $\mathrm{e}=$ margin error $(0.05)$

$\mathrm{n}=\mathbf{3 6 5}$

$1+365(0.05)^{2}$

$=190$

Table 1: Sample Frame

\begin{tabular}{lll}
\hline Category & No. of Schools & Sample size \\
\hline National school & 2 & 1 \\
Extra-County school & 22 & 12 \\
County school & 43 & 22 \\
Sub-County school & 298 & 155 \\
\hline Total & $\mathbf{3 6 5}$ & $\mathbf{1 9 0}$
\end{tabular}

\section{Source: Research Data (2020)}

Structured questionnaire was used as the main source of data collections. The questionnaire had both open ended and closed ended questions which was structured based on the research objectives. The validity of the instrument was ensured by subjecting to the scrutiny of the experts from the subject area. Reliability was ascertained by conducting a pilot study in Nyamira County with different group of respondents who did not contribute in the actual study. Nyamira County was preferred for piloting because it had similar characteristics with the targeted county. Reliability was tested using Cronbach Alpha were a coefficient of 0.87 was actualized thus the research instrument was deemed acceptable (Cohen, Manion and Morrison, 2005).

A multiple linear regression was used to establish the link between the degree in which accounting practices relate with management of funds among public secondary schools in Kisii County.

The regression model adopted was;

$(\mathrm{Y})=\beta 0+\beta 1 \mathrm{X}_{1}+\beta 2 \mathrm{X}_{2}+\beta 3 \mathrm{X}_{3}+\beta 4 \mathrm{X}_{4}+\varepsilon$

Where: $Y=$ management of public funds, $\beta 0=$ Constant, $\beta_{1}=$ Beta Coefficient of $X_{1}, X 1=$ Budget practices, $\beta_{2}=$ Beta Coefficient of $\mathrm{X}_{2}, \quad \mathrm{X} 2=$ Book keeping practices, $\beta_{3}=$ Beta Coefficient of $\mathrm{X}_{3}, \mathrm{X} 3=$ Internal Control, $\beta_{4}=$ Beta Coefficient of $\mathrm{X}_{4}$, $\mathrm{X} 4$ = Automation Accounting, $\varepsilon=$ Error term 
The collected data was edited for accuracy, reliability and dependability as well as extensiveness and then evaluated using inferential and descriptive statistics with the help of the Statistical Package for Social Studies. Descriptive statistics include measures of central tendency like the mean, percentages and the standard deviation while inferential statistics was used to draw conclusions. The study sought for the consent and authorization for respondents through the use of an introductory letter, secrecy was guaranteed all through the information gathering process since the names of the respondents won't be demonstrated in the exploration instruments. Permission was sought from university and NACOSTI before data collection.

\section{FINDINGS AND DISCUSSIONS}

This study attained a response rate of $93.7 \%$ where 178 out of 190 . According to Mugenda and Mugenda (2003) above $80 \%$ response rate is an excellent data that can be used for further interpretation. This was further supported by Babbie (2002) argument that the response rate of $60 \%$ is good, $70 \%$ is very good and $50 \%$ is adequate for analysis, therefore the response rate of $93.7 \%$ was very good.

Regression model was which involved correlation coefficient, coefficient of determination and regression model were used to explain the relationship between accounting processes and funds' management. The result was further interpreted to obtain viable information as indicated in the tables.

\section{Table 2 Regression Analysis}

\begin{tabular}{|c|c|c|c|c|c|c|c|}
\hline \multirow[t]{2}{*}{$\mathbf{R}$} & \multirow[t]{2}{*}{$\begin{array}{l}\text { R } \\
\text { Square }\end{array}$} & \multicolumn{5}{|c|}{$\begin{array}{l}\text { Adjusted R Std. } \\
\text { Error Change Statistics } \\
\text { Square of the }\end{array}$} & \multirow{2}{*}{$\begin{array}{l}\begin{array}{r}\text { Durbin- } \\
\text { Watson }\end{array} \\
\text { F }\end{array}$} \\
\hline & & & Estimate & $\begin{array}{l}\text { R Square F Chang } \\
\text { Change }\end{array}$ & df1 df2 & $\begin{array}{l}\text { Sig. } \\
\text { Change }\end{array}$ & \\
\hline $.939^{\mathrm{a}}$ & .882 & .879 & .34286 & 322.118 & 173 & .000 & 1.651 \\
\hline
\end{tabular}

Source: Research Data (2020)

The result from Table 2 indicates that there was strong correlation between accounting process and funds' management representing by correlation of $0.939(\mathrm{R}=0.939)$. It was found that the coefficient of determination which was given by $\mathrm{R}$ Square $=$ 0.882 indicated that $88.2 \%$ of the variation of fund's management was due to accounting processes, while other factors was explained the remaining $21.8 \%$. This reveals that the independent variables adopted by the study explained $88.2 \%$ of accounting principles while the $21.8 \%$ is explained by other variables not adopted by the study.

Table 3 ANOVA for Accounting Practices and Funds Management

\begin{tabular}{lllllll}
\hline Model & & Sum of Squares & df & Mean Square & F & Sig. \\
\hline \multirow{2}{*}{1} & Regression & 151.461 & 4 & 37.865 & 322.118 & $.000^{\mathrm{b}}$ \\
& Residual & 20.336 & 173 & 0.118 & & \\
& Total & 171.798 & 177 & & &
\end{tabular}

a. Dependent Variable: Funds Management.

b. Predictors: (Constant), Automation in accounting, Budgeting, Bookkeeping, Internal Control

\section{Source: Research Data (2020)}

The regression model was appropriate for testing the relationship which indicated that accounting process was significantly related to the funds' management $(\mathrm{P}<0.05)$. The mean square of the residuals was very small $(0.118)$ compared to mean square of the regression (37.865). Further, the F-statistics of the regression $\left(F_{(4,173)}=322.118\right)$ which was statistically significant $(\mathrm{p}<0.01)$ indicates that the model significantly predict the change of the dependent variable as a result of the four predictor variables included in the model. This implies that the coefficients of the model are not equal to zero, suggesting that the model fits the data significantly. Hence, there is significant relationship between accounting process practices and fund's management.

These findings concurs with those of Langat (2008), who noted that the administration monetary guidelines had restricted the intensity of the school heads to subjectively decide and control the financing of physical offices. The examination additionally discovered that administration guidelines had all around controlled staff preparing in the schools to coordinate their necessities and assets and encouraged the handling and update of data in the budget reports as prove by improved administration, straightforwardness and responsibility in the schools' intermittent uses (Omoro, 2005). 
The findings that school have adopted better accounting practices so as to ensure accountability in funds management by use of internal control of funds thus reducing on financial risk through accounting processes and automation concurs with Njeru (2004) who established that in cash management practices head teachers need to embrace a systematic approach to financial management.

Table 3 Regression Coefficients

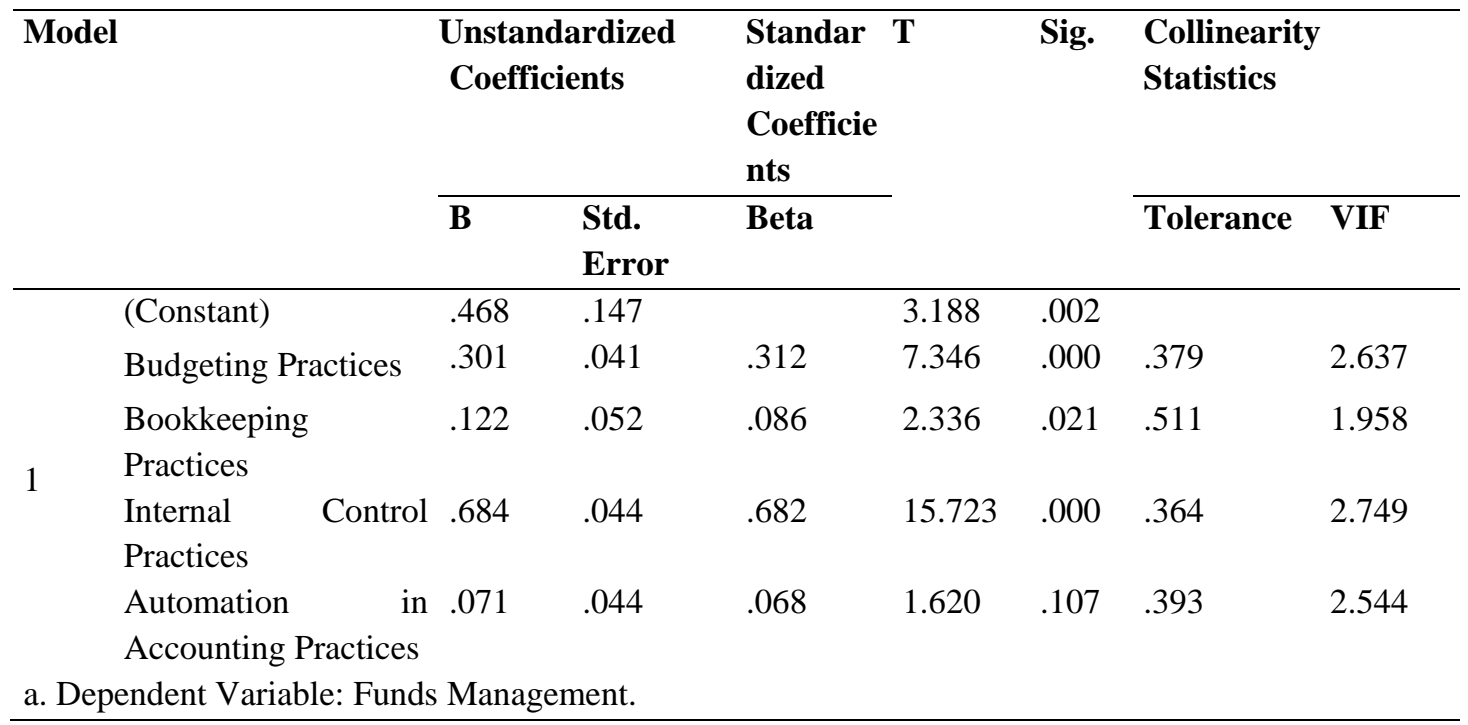

Source: Research Data (2020)

$\mathrm{Y}=0.468+0.301 \mathrm{X}_{1}+0.122 \mathrm{X}_{2}+0.684 \mathrm{X}_{3}+0.71 \mathrm{X}_{4}$

Where: $\mathrm{Y}=$ management of public funds

$\beta 0=$ Constant

$\mathrm{X} 1=$ Budget practices

$\mathrm{X} 2$ = Book keeping practices

$\mathrm{X} 3=$ Internal Control practices

$\mathrm{X} 4$ = Automation Accounting practices

This results indicates that one-unit increase in budget practices would results to 0.301 increase in funds' management, a unit increase in bookkeeping practice would result into 0.122-unit increase in funds' management, a unit increase in internal control practices leads to 0.684 increase in funds' management and finally a unit increase in automation accounting practices lead to 0.071 increase in funds' management. Hence internal control practices were followed by budgeting practice then book keeping were significant and assist in management of funds. While automation accounting practices were not significant on fund's management.

The result showed that budgeting practices was significant since it had a significance of $0.000,(\mathrm{P}<0.05)$, bookkeeping practices has a significance of $0.021(\mathrm{P}<0.05)$ and internal control practices had a significance of $0.000(\mathrm{P}<0.05)$, all the three significantly affected the funds' management since the $\mathrm{P}<0.05)$. The results indicated automation accounting practices did not significantly affect funds management since it had a significance value of 0.107 which is higher than $(\mathrm{P}>0.05)$. The success to good accounting practices relies on well trained as well extremely inspired bursars who will relieve head teachers as well as other members of the management team from a broader of school administration jobs. Though the head teacher is the principal accounting officer in the school, the officers to whom he has delegated the responsibility of bookkeeping should be competent, (Otieno \& Nyangechi, 2013). This findings concurs with those of Dallu (2016) who noted that applicable data must be recognized, caught and imparted in a shape and time span that enables workers to complete their undertakings in a proficient and viable way.

\section{SUMMARY, CONCLUSIONS AND RECOMMENDATIONS}

The result on budget practices showed high participation of stakeholders in budget preparation (mean of 3.618). It was found that financial budget was vetted annually in majority of the school for financial transparency (mean of 3.848). Financial budgets estimates were adhered to some extent with less deviation from the actual amounts (mean of 3.090). The finding revealed that most school did not depend on accounting experts in budget estimate but relied on the existing bursar for funds management (mean of 2.814). It was then revealed that management conducted comparison of current spending's and budget estimates to enhance management in finance (mean of 3.624). The budgeting practices was found to positive significant to the funds management 

practices.

Bookkeeping was found to be crucial as accounting practices since proper receipts and invoicing would assist in paper trailing for purpose of transparency (mean of 3.899). The finding indicated that school prepared journal vouchers, cashbook and ledger book for accountability (mean of 4.742). The results further indicated that school are paid using cheques and banks slip to ensure that fees are well recorded and managed (mean of 3.208). It was further revealed that government disbursements accounts were well maintained and accounted for accountability purposes (mean of 4.506). Hence financial statement was produced for more accountability purpose as well as transparency (mean of 4.624). It was found that bookkeeping practices was positively related to funds' management $(\mathrm{r}=0.000, \mathrm{P}<0.05)$. It was the third factor that affected funds management after internal control and budgeting practices.

Internal control practices were found to be crucial for management of funds in school. This assisted in management of school asset where all asset must be accounted and recorded for (mean of 4.640). The control also involved management of use of money as well as access to funds (mean of 4.253). It was found that adequate documentation and maintenance of school records are used in controlling finance (mean of 4.365). It was found that verification and reconciliation of accounts assisted in financial management (mean of 4.140). It was found that monitoring was not done frequently (mean of 2.449). Hence internal control significantly and positively affected funds management $(\mathrm{r}=0.000, \mathrm{P}<0.05)$. Internal control practice was found to be leading in accounting process when management funds.

Automation in accounting is first growing concept that enable accounting to be computerized. The findings indicated that the schools embraced m-banking concept in sending and receiving money (mean of 4.197). There are school who are currently utilizing the electronic accounting software that provide accurate and efficient reporting of financial statement (mean of 3.905). According to further findings on financial statement automation is done in storage documentation in soft copy (mean of 4.045). Hence bookkeeping are becoming computerized and storage are done in computer (mean of 4.039). The institution has encouraged innovation and funds management so as to reduce risk (mean of 4.006). Hence automation has no significant relationship with management of funds since it had a significance of $(\mathrm{r}=0.107, \mathrm{P}<0.05)$.

It concluded its important stakeholders be involved in budget preparation enabled the management. The financial budget must undergo vetting annually by the stakeholders. It was also found that school rarely dependent on accounting experts but checked whether the estimates are attained through employed bursars. The research revealed that budgeting as a practice was significant on ensuring that financed were managed well. It enables the school to reduce over spending and hence manage the financial performance of the school. The research concluded on bookkeeping to be significant in management of funds since it allows the school to keep trail of all transaction that are conducted. School keep records through the use of receipt books, journal vouchers, ledger books which were used to produce financial statement which includes cash flow, balance sheet and income statement. The research also found that cheques and bank slip were preferred for accountability and managing funds. All government disbursements were well accounted and hence bookkeeping is a crucial aspect of accounting. Hence bookkeeping had significant relationship with funds management.

Internal control practices were found to assist a lot in management of funds. It the highest contributor in management of funds'. The research concluded that most school ensured all asset were well recorded and management to ensure accountability. There existed control in use and access to money as well as documentation of all transaction to ensure financial control. The school also provided verification and reconciliation of all accounting for proper financial management. Also there exist few monitoring and evaluation in internal controls which are necessary to be addressed. Hence internal control has significant positive relation to funds' management. The study concluded that automation through m-banking and electronic accounting software are some of emerging issues. The software's are found to assist in providing accurate results as well as encourage storage of bookkeeping. The institution has encouraged use of innovation in funds management as well as use of technology in receiving and sending money. Despite the growth in innovation and use of automation this has no significantly influenced the management of funds.

The research recommends to the school to conduct training and employee qualified bursars and ensure that accounts are well budgeted. The targeted budget should be with minimal deviation from the exact value. The research recommends to school management to involve experts in trainings to reduce redundancy in funds management. Bookkeeping assist a lot in paper trail, accountability and transparency. It is important for school to emphasis on use of cheques and banks slips to management finance. It also crucial for daily records to be prepared for management of funds. There is a need for daily preparation of necessary recording of information to ensure that all that financial statements are well prepared. The study recommends in internal control that there is need to increase internal control practices since there was laxity in monitoring and evaluation of internal control process. These elapses have negative effect on the management of funds. Since internal control practices assisted to a large extent the funds' management. 
The study also recommends to management to further investigate on innovation especially the use of accounting systems. This is because there are lack of standard software as well as poor legislation on the use of electronic system of accounting. The ministry of education should provide standardized accounting system that would ease the use of accounting systems.

\section{SUGGESTIONS FOR FURTHER RESEARCH}

There is need to investigate the use of accounting system in funds' management. This is to investigate whether they significantly contribute to accuracy, transparency and accountability in financial management. The study also recommends on the need to further investigate on the internal control mechanism in funds management. This is to clarify where most funds are managed especially in school setup.

\section{REFERENCES}

(1) Bayyoud, M. \& Sayyad, N. A. (2015). The impact of internal control and risk management on banks in Palestine. International Journal of Economics, Finance and Management Sciences, 3(3), 156-161

(2) Colbert, G., \& Murray, D. (1998). The association between auditor quality and auditor size: an analysis of small CPA firms. Journal of Accounting, Auditing and Finance, 13 (2), 135-150.

(3) Davoren, J. (2015). Contingency theory in auditing. Texas, USA: Houston Chronicles

(4) DeAngelo, L. (1981). Auditor size and audit quality. Journal of Accounting and Economics, 11 (3), $183-199$.

(5) Davis, J. H., Schoorman, D. F. \& Donaldson, L. (1997). Toward a stewardship theory of management. Academy of Management Review, 22 (1), 20-47.

(6) Grace, K., \& Ambrose, J. (2013). Institutional investors' perceptions on quality of financial reporting in Kenya. International Journal of Humanities and Social Science, 3(21), 144-156.

(7) Gelinas, U., Sutton, S. \& Hunton, J. (2005). Acquiring, developing and implementing accounting information system. Thomson South-Western Education College, Cincinnati

(8) Hopwood, W., McKeown, J.C., \& Mutchler, J. (1994). A re-examination of auditor versus model accuracy within the context of the going-concern opinion decision. Contemporary Accounting Research, 10(2), 409-431. doi/10.1111/j.19113846.1994.tb00400.x

(9) Horvat, T. (2007). Leader accountability for school financial management. international congress for effectiveness and improvement

(10) Ijaduola, K. O. (2008). Achieving the Millennium Development Goals (MDGs) in Nigeria: educational planning option. Journal of Research in National Development, 6 (2), 28-40.

(11) Kaguri, M., Njati, I. C. \&Thiaine, K. S. (2014). Financial management challenges facing implementation of free day secondary education in Imenti North District, Kenya. IOSR Journal of Business and Management, 16(1), 55-78

(12) Kalui F. M., \& Mbakaya, J. A. (2014). An analysis of audit quality attributes and client satisfaction for companies quoted at Kisii Securities Exchange, Scholarly Research, 1(5), 764-785.

(13) Kamau, C.G., \& Kariuki, S.N. (2012). Factors influencing sample size for internal audit evidence collection in the public sector in Kenya, International Journal of Advances in Management and Economics, 1(2), 42-49.

(14) Keasey, K., \&, Wright, M. (1993). Issues in corporate accountability and governance: An editorial. Accounting and Business Research, 23(91A), 291-303.

(15) Kimutai, I. (2012). The expectation gap in the statutory audits of quoted companies in Kenya. Unpublished master's thesis, Kenyatta University.

(16) Kiriza, R. K., Walela, K. B. \&Kukubo, D. W. (2015). Financial management in public secondary schools in Kenya: A case study of Lurambi Sub-County Kakamega County. International Journal of Scientific \& Technology Research, 4 (9), 167 $-178$ 
(17) Koross, P. K., Ngware, M. W. \& Sang, A. K. (2008). Principals and students' perceptions on parental contribution to financial management in secondary schools in Kenya. Egerton University.

(18) Kothari, C. R. (2004). Research Methodology. New Age International (P) Limited Publishers

(19) Kung'u, J. N. \& Mwangi, J. K. (2014). Effects of fund management practices on financial performance in cdf funded water projects in Kenya. IOSR Journal of Economics and Finance, 5(3), 53-60

(20) Langat, G. K. (2008). An evaluation of the impact of government instructions on financial management in public secondary schools in Kenya. Unpublished Project. Egerton University.

(21) Maseko, N. \& Manyani, O. (2011). Accounting practices of SMES in Zimbabwe: An investigative study of record keeping for performance measurement (A case study of Bindura). Journal of Accounting and Taxation, 3(8), 171 - 181

(22) McKeon, J.C, Mutchler, J.F., \& Hopwood, W. (1991). Towards an explanation of auditor failure to modify the audit opinions of bankrupt companies. Auditing: A Journal of Practice and Theory, 10, 1-17.

(23) Merireng, S. (2013). Effect of computers in management of secondary schools in Kenya: A case of West Pokot County, Kenya. Unpublished Project. University of Kisii.

(24) Mobegi, F. O., Ondigi, B. A. \&Simatwa, E. M. (2012). Factors contributing to financial mismanagement and misappropriation in public secondary schools in Gucha District, Kenya. IJEMR, (5), 1 - 18

(25) Munge, M. N., Kimani, M. \& Ngugi. D. G. (2016). Factors influencing financial management in public secondary schools in Nakuru County, Kenya. International Journal of Economics, Commerce and Management, 4(9), 91-114

(26) Myers, J., Myers, L., \& Omer, T. (2003). Exploring the term of the auditor-client relationship and the quality of earnings: A case for mandatory auditor rotation? The Accounting Review, 78 (3), 779-798.

(27) Ndu, A. N, Ocho, L.O. \& Okeke, B.S. (1997). Dynamics of educational administration and management: The Nigerian perspective. Meks publishers.

(28) Ngware, M. W., Onsomu, E. N., Kiriga, B. and Muthuka, D. I. (2007). Free secondary education in Kenya: Costs, Financing sources and implications. KPPRA Discussion Paper, No.75 Kenya.

(29) Njeru, J. W. (2004). Financial management practices of the head teachers in public secondary schools in Central Division, Embu District, Kenya. Unpublished MEd Project. University of Kisii

(30) Nombasa, N. S. (2004). Self-managing schools in Gauteng: challenges and opportunities for school based managers: Unpublished Thesis; University of South Africa

(31) Nupakorn, H. \& Phapruke, U. (2010). Accounting practice effectiveness and financial performance of Thai listed firms: mediating effects of decision making efficiency for tax management, competent resource allocation, and strategic planning success. European Journal of Management, 10(1), 1-10

(32) Nyakundi, N., Okioga, C., Ojera, P., Nyabwanga, R. N. \& Nyamwamu, T. O. (2013). An assessment of the effect of accounting practices on the management of funds in public secondary schools: A study of Kisii Central District, Kenya. Asian Journal of Business and Management Sciences, 2(8), 34-50

(33) Okumbe, J. A. (1998). Educational management theory and practice: Kisii University Press.

(34) Omondi, M. A., Sangoro, O., Atieno, J., Odongo, T. O. \& Rono, L. (2016). Evaluation of the Role of Control Systems on Financial Management in Public Secondary Schools: A Case of Kakamega Central District. IJRDO-Journal of Applied Management Science, 1(9), 27 - 56

(35) Omoro N. O. (2005). Financial reporting in public secondary schools in Kenya and the audit expectation gap: A survey of public secondary schools in Kisii. Unpublished MBA Project. University of Kisii

(36) Ostergren, K. \& Stensaker, I. (2011). Management control without budgets: a field study of 'beyond budgeting' in practice. European Accounting Review, 20(1), 149-181

(37) Otieno, S. \&Nyangechi, E. O. (2013). Effectiveness of internal control procedures on management efficiency of free secondary education funds: a case of Public Secondary schools in Kisii central District, Kenya. Journal of Sociology and Social Work, 1(1), 22-41

(38) Oyugi, L. N. (2010). Public expenditure tracking of secondary education bursary scheme in Kenya. Kenya Institute of 
policy Analysis and research.

(39) Republic of Kenya. (2008). Radical reform for Kenya's educational sector, publication management instructions for educational institutions: (1st Edition). Kisii; Government Printer

(40) Sigilai, R. M. \&Bett, J. C. (2013). An assessment of head teachers' effectiveness in managing public secondary school finances in Bomet Sub-County, Kenya. Journal of Emerging Trends in Educational Research and Policy Studies, 4(2), 205-209

(41) The Kenya Basic Education Act (2013). Kenya Gazette Supplement; Government Printer, Kisii.

\section{Authors}

(1) Grace Ndinda Kimuyu, Researcher, University of Kabianga, gndida4@gmail.com

(2) Dr. Isaac K. Naibei, Senior Lecturer, University of Kabianga, inaibei@kabianga,ac.ke

(3) Dr. Hellen W. Sang, Senior Lecturer, University of Kabianga whellensang@ gmail.com

\section{Corresponding Author: inaibei@kabianga.ac.ke}

